\title{
RALPH LINTON
}

On December 24, 1953, Ralph Linton completed a very active and productive life span. He would have been 61 years old on February 27, 1954. Born in Philadelphia, in 1893, he received the B.A. degree at Swarthmore College in 1915, the M.A. degree at the University of Pennsylvania in 1916, and the Ph.D. degree at Harvard University in 1925. He was Research Associate in Ethnology at the B. P. Bishop Museum, Honolulu, 1919-20; Assistant Curator of Ethnology at the Field Museum of Natural History (now the Chicago Natural History Museum), 1922-28; Professor of Anthropology, University of Wisconsin, 1928-37; Professor of Anthropology, Columbia University, 1937-46 (Chairman 1939-43); and Sterling Professor of Anthropology at Yale University from 1946 to the time of his death.

It should be emphasized that Linton was an anthropologist in the broadest sense of the term, his active interests covering every somewhat controversial subdivision of that somewhat controversial term. It was during a discussion with the writer that Linton, during the last year of his life, speaking of the interdependence of all social studies, expressed the opinion that any definition for one of the various subject aspects of anthropology was arbitrarily loose, since, no matter what the restrictions set forth in the definition might be, the student in the subject field so defined would have to transgress the boundaries so prescribed in order to be equipped with adequate background to do his work.

The specific purpose of these obituary comments is to review Linton's work in, and conceptual attitude toward that loosely defined approach to the study of human society which we call archaeology.

Linton's early field experience was almost exclusively in archaeology. In 1912 he had his first taste of field work in New Mexico. In the following year he spent one season in Guatemala, while a student at Swarthmore. After graduating from college, and entering the graduate school at Pennsylvania, his continued interest induced him to participate in archaeological projects in New Jersey and Illinois.

World War I interrupted Linton's graduate work at Harvard, and shortly after his discharge from the U.S. Army, he joined the crew working under J. Walter Fewkes at Mesa Verde National Park, Colorado. Immediately following, he participated in the Bayard Dominick Expedition, directed by the B. P. Bishop Museum of Honolulu, assigned to the Marquesas Islands with instructions to cover archaeology and material culture. However, his growing interest in the total human picture, and his natural tendency to avoid specialization led him to begin a study which ultimately included all of Polynesia: its peoples, their cultures, their histories, and their status within the frame of human society. He felt it to be quite impossible to report on the material culture of the Marquesas without at least an introductory review of Marquesan social organization and religion.

In 1924, while employed as Assistant Curator of Ethnology at the Field Museum of Natural History, Linton collaborated in archaeological investigations in Ohio, which served to focus his interest in middlewestern archaeology, an interest which, rather than being submerged by his teaching and writing activities in a more general field, were incorporated into a comprehensive approach to American-wide and world-wide archaeology, and integrated with his expanding social concepts. 
Upon Linton's return from his ethnological studies in Madagascar, he was appointed Professor of Anthropology at the University of Wisconsin; and, in 1935, he completed arrangements for an archaeological project in Wisconsin financed by the University, and conducted by the Division of Anthropology, Milwaukee Public Museum. This agreement between the two institutions resulted in two summer-long field projects which brought to the attention of local archaeologists a new cultural manifestation: The Clam River focus, a protohistorical culture featured by compound burials in large mounds, and tentatively identified with the Sisseton Sioux. Unfortunately for this project, previous to the publication of any results, Linton left Wisconsin. With his departure there ensued a lapse in organized archaeological research in that state enduring for more than a decade.

Linton was always alert to the possible significance of factual data supplied through archaeological efforts. He was the first to postulate the probable Siouxan origin for the Clam River mounds. He became an enthusiastic supporter of the hypothesis for the Asiatic origin of the Woodland type of pottery, and of an Archaic affinity for the heavily corroded, utilitarian copper implements of the Wisconsin area. He encouraged investigation into the problem of sub-Arctic, even circum-polar prototypes for these artifacts. Although his primary interest was in people and social phenomena rather than in research methods, he manifested a keen interest in efforts to apply taxonomy to archaeological procedure.

Realizing the essential importance of time to any comprehensive study and understanding of the functioning of culture, and conscious of no separation between cultural activities and material equipment - knowing from personal observation that a drum, a ceremony employing that drum, and a concept motivating that ceremony, are inseparably linked parts of cultural activity, Linton was as interested in material products, whether of ancient or recent origin, as he was in the activity and concept which they represent. He delighted in exhibiting his extraordinary memory for details by identifying the place and character of some obscure museum specimen, or correcting the false identification appearing on a label. This was a part of his equipment toward attempting to visualize as a whole the complex pattern of human society: the adjustments of the individual to cultural tradition, as modified by natural and social environment, manifested in practices which require the use of environmental materials, subject to change through growth in time.

Linton is best known for the ideas expressed in such books as The Study of Man, not for his relatively minor publications on archaeological subjects as such; but the archaeologist can find in practically any one of Linton's more important contributions matter of interest to archaeologists, derived from a wide knowledge of archaeologically produced data. His loss to archaeology is that of one who, more indirectly than directly a contributor to the subject, nevertheless knew and acknowledged the place of archaeology in the discipline of anthropological study, and applied that knowledge throughout his work as a teacher and writer.

In spite of accusations that he was opinionated, intellectually competitive, and professionally suspicious, even though these judgments may be not wholly unjustifiable, his very critics must admit that Ralph Linton possessed one of the most intelligently alert, brilliantly productive minds in the field of anthropology for his generation. 
not, as some nineteenth century botanists have supposed, the related grass, teosinte.

Yet teosinte (or another related grass, Tripsacum) has cleatly played an important part in the evolution of make. Prehistoric cobs from other caves show evidence of the contamination of domesticated maize by teosinte. This evidence comes from Cebollita Cave in New Mexico, from two caves in Arizona, and a cave in Chihuahua, Mexico. These were explored respectively by Reynold Ruppe of the Peabody Museum of Harvard University, Lloyd M. Pierson of the National Park Service, and Robert $H$. Lister of the University of Colorado Museum. In the material from each of these caves there are specimens of cobs which show strong evidence of contamination by teosinte. Furthermore, it is possible to match some of the archaeological specimens almost exactly with synthetic types produced by actually hybridizing maize and teosinte. The hybridization of maize and teosinte may have been a comparatively recent event in the history of maize under domestication. In the material from Cebollita Cave the early maize is all "pure" maize while the more recent material shows strong evidence of contamination.

Although there are many questions yet to be answered, the main features of corn's origin and evolution are now reasonably clear. The American Indians apparently domesticated maize wherever they found it. Domesticated varieties originating from distinct geographical races soon hybridized to create new and more productive types. Still later corn crossed with teosinte. To new races resulting from this cross teosinte contributed not only resistance to drought and diseases and the structural strength needed for the development of large plants and ears, but also mutability.

All of these factors combined to speed the evolution of maize to a point beyond that of perhaps any other cultivated plant. In 6000 years, or less, a small wild grass bearing tiny ears no larger than a modern strawberry has evolved into one of the world's most productive cereals. The evolution of maize has been truly explosive. Most of the factors involved in this extremely rapid evolution have been largely accidental. There is little evidence that man practiced artificial selection in maize in the early stages of domestication, or if he did, no evidence that he succeeded. His role was primarily one of creating opportunities for hybridization between races of maize and between maize and its wild relatives. But when man finally did begin to practice selection, he had a rich diversity at his disposal from which it was possible to choose a combination of characteristics that have made maize one of the most efficient of all cereals as a producer of foodstuffs.

Paul C. Manghlsdorf
Botanical Museum
Harvard University
Cambridge, Massachusctts

\section{RALPH LINTON (Continued from page 383)}

\section{BIBLIOGRAPHY *}

1916. (With Ernest W. Hawkes.) A Pre-Lenape Site in New Jersey. University of Pennsylvania Anthropological Museum Publications, Vol. 6, No. 3.

1917. (With Ernest W. Hawkes.) Pre-Lenape Culture in New Jersey. American Anthropologist, Vol. 19, pp. 487-94.

1924. Origin of the Plains Earth Lodge. American Anthropologist, Vol. 26, pp. 247-57.

1924. Significance of Certain Traits in North American Maize Culture. American Anthropologist, Vol. 26, pp. 345-9.

\footnotetext{
* Restricted to archaeology and selected general contributions which cuntain material of specific interest to the archaeologist.
}

1925. Archaeology of the Marquesas Islands. Bernice P. Bishop Museum, Bulletin 23.

1936. The Study of Man. New York: D. AppletonCentury Co.

1938. Present Status of Anthropology. Science, Vol. 87, pp. 241-8.

1944. North American Cooking Pots. American Antiquity, Vol. 9, pp. 369-80.

1944. Nomad Raids and Fortified Pueblos. American Antiquity, Vol. 10, pp. 28-32.

1951. New Light on Ancjent America. Scientific Monthly, Vol. 72, pp. 313-17. 